\title{
Male meiosis and meiotic abnormalities in two species of Pouzolzia Gaud. from western Himalayas, India
}

\author{
Lovleen $^{1}$ and Manjit Inder Singh Saggoo
}

Department of Botany, Punjabi University, Patiala-147002, India.

${ }^{1}$ Author for correspondence: (ms.lovleen7@gmail.com)

Received December 21, 2013; accepted January 23, 2014

\begin{abstract}
The present investigation involves the meiotic studies on two species of Pouzolzia (family Urticaceae) from western Himalayas, India. Both the species uniformly revealed chromosome count of $2 n=26$ which is first ever chromosome report for Pouzolzia pentandra (Roxb.) Benn. on worldwide basis and first chromosome report for Pouzolzia hirta (Blume) Hassk. from western Himalayas. This is also the first report of cytomixis in P. hirta. In addition to bridge formation and extra chromatin material, chromosome stickiness was the most frequent meiotic chromosomal anomaly found in both the species. In spite of abnormalities there was no adverse effect on pollen fertility. Morphological analysis of $P$. pentandra revealed the existence of two morphotypes.
\end{abstract}

KEYWORDS: Chromosome stickiness, Cytomixis, Morphotypes, Pouzolzia hirta, Pouzolzia pentandra, Western Himalayas

Pouzolzia Gaud., family Urticaceae, is distributed in Asia, Australia and South Africa. Worldwide, the genus is represented by 36 species and 17 infraspecific taxa (Wilmot-Dear and Friis 2004). Of the total 13 species of the genus available in India two are discussed here.

Pouzolzia hirta (Blume) Hassk. [= Gonostegia hirta (Blume) Miq.] is an annual decumbent or semi- erect pubescent herb with cylindrical stem. The leaves are opposite, sessile or shortly stalked, narrowly ovate, entire with acute apex. Flowers are pale green in colour and are present in small rounded dense clusters. It is distributed worldwide in India, China, Indonesia, Malaysia and Australia. In India, P. hirta (Blume) Hassk. is found in tropical and sub-tropical Himalayas from Himachal Pradesh to north eastern states upto $1600 \mathrm{~m}$ altitude. It is a medicinally important herb and the root paste is used to treat the bone fracture and bandaged around the affected area (Saha et al. 2011). Tender leaves and stems are used as vegetable to improve the appetite and lactation in women (Srivastava 2009; Shankar et al. 2012). The plant is used as fodder too. This species has been studied from eastern Himalaya and chromosome counts of $2 \mathrm{n}=16$, $2 \mathrm{n}=26$ and $2 \mathrm{n}=32$ are known (Sharma and Sarkar 19671968; Sharma 1970; Sharma and Mehra 1977; Guha 1977; Chatterjee et al. 1989).

Pouzolzia pentandra (Roxb.) Benn. [= Gonostegia pentandra (Roxb.) Miq.] is an annual, erect, nearly glabrous herb with robust, angular stem (Fig. 1). Leaves are opposite below, the upper alternate, crowded, gradually decreasing in size upwards, sessile or shortly stalked, oblong-lanceolate, entire with acute apex. Flowers are loosely clustered in upper leaf axils. It is distributed upto $1,000 \mathrm{~m}$ in India, China, Java, Pakistan, Afganistan, Bangladesh, Indonesia, Myanmar, Papua New Guinea, Philippines, Thialand and Vietnam. In India the species is found in subtropical and tropical Himalayas from Kangra eastward to Assam Khasia Hills and Bengal to Kanara in south. It is a great medicinal plant and is used as one of the ingredient in anti-cancer remedies in Thai traditional medicines. The plant exhibits the growth-inhibiting effects against bacterium named Helicobactor pylori known to cause various gastric ailments (Chaichanawongsaroj et al. 2012).

To the best of our knowledge chromosome studies are lacking in both the above species of medicinal importance from western Himalayas. The present study aims to fill the gap in knowledge of the basic information about chromosome number, meiotic behaviour and pollen fertility in various wild populations of the species of Pouzolzia from western Himalayas.

\section{Material and Methods}

Materials for meiotic studies and morphometeric analysis

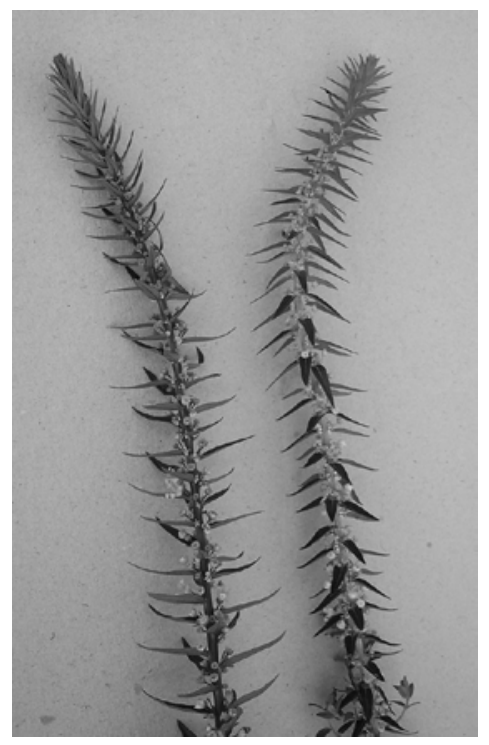

Fig. 1. Inflorescences of two morphotypes of Pouzolzia pentandra (Roxb.) Benn. as the yellowish-green colored stem (right) and the red colored stem (left) 
Table 1. Comparative data on meiotic course, pollen fertility and pollen size of various accessions of Pouzolzia hirta (Blume) Hassk. and Pouzolzia pentandra (Roxb.) Benn. from western Himalayas, India

\begin{tabular}{|c|c|c|c|c|c|c|c|}
\hline \multirow[b]{3}{*}{ Population } & \multirow{2}{*}{\multicolumn{4}{|c|}{ Pouzolzia hirta (Blume) Hassk. }} & \multicolumn{3}{|c|}{ Pouzolzia pentandra (Roxb.) Benn. } \\
\hline & & & & & \multicolumn{2}{|c|}{ Morphotype Green } & \multirow{2}{*}{$\begin{array}{c}\text { Morphotype Red } \\
\text { Rehlu,900m }\end{array}$} \\
\hline & Palampur, $1,100 \mathrm{~m}$ & Beerta, $730 \mathrm{~m}$ & Bhagsunag, $1,900 \mathrm{~m}$ & Sali, $1,500 \mathrm{~m}$ & Rehlu,900m & Dheera, $500 \mathrm{~m}$ & \\
\hline Accession number (PUN) & 58579 & 58580 & 58582 & 58581 & 58583 & 58585 & 58584 \\
\hline Chromosome number (n) & 13 & 13 & 13 & 13 & 13 & 13 & 13 \\
\hline Ploidy level & Diploid & Diploid & Diploid & Diploid & Diploid & Diploid & Diploid \\
\hline \multicolumn{8}{|l|}{$\begin{array}{l}\text { PMCs with meiotic } \\
\text { abnormalities }(\%)\end{array}$} \\
\hline Bridges at A-I & 1.18 & - & - & - & - & - & - \\
\hline Extra chromatin material & 6.51 & - & - & - & - & 0.61 & 0.57 \\
\hline Chromatin stickiness & 81.66 & 94.03 & 97.36 & 96.76 & 87.03 & 81.69 & 44.83 \\
\hline \multicolumn{8}{|l|}{ Cytomixis } \\
\hline$\%$ PMCs involved & 11.24 & - & - & - & 1.71 & 4.38 & 12.81 \\
\hline No. of PMCs involved/ event & $2-3$ & - & - & - & 2 & $2-3$ & $2-3$ \\
\hline Meiotic stages & Diakinesis, M-I & - & - & - & M-I & Diakinesis & Diakinesis, T-I,M-II,T-II \\
\hline \multicolumn{8}{|l|}{ Pollen } \\
\hline Pollen Fertility (\%) & 92.67 & 100 & 99.46 & 99.73 & 99.77 & 98.13 & 99.64 \\
\hline Pollen size $(\mu \mathrm{m})$ & $10.56 \times 10.19$ & $10.76 \times 9.92$ & $10.32 \times 9.60$ & $9.84 \times 9.07$ & $13.19 \times 12.89$ & $13.40 \times 12.47$ & $12.60 \times 12.01$ \\
\hline
\end{tabular}

PMC= pollen mother cell; M-I= metaphase-I; A-I= anaphase-I; M-II= metaphase-II; T-I=telophase-I; T-II=telophase-II

in Pouzolzia pentandra (Roxb.) Benn. were collected from different locations in western Himalayas of India (Table 1; Fig. 1). Identification of the specimens was done at Botanical Survey of India, Dehra Dun, India. Voucher specimens were deposited in the Herbarium, Department of Botany, Punjabi University, Patiala (PUN).

The young floral buds of suitable sizes were fixed in Carnoy's fixative (6 ethanol: 3 chloroform: 1 acetic acid $\mathrm{v} / \mathrm{v}$ ) for $24 \mathrm{~h}$ and then preserved in $70 \%$ alcohol at $4{ }^{\circ} \mathrm{C}$ until use. For meiotic studies, anthers were squashed in $2 \%$ acetocarmine (BDH product). A number of slides were carefully examined for chromosome counts and meiotic abnormalities at different stages in each population. Pollen fertility was examined using glycerolacetocarmine mixture (1:1) (Marks 1954). Well filled pollen grains with stained nuclei were taken as apparently fertile while shriveled and unstained pollen were counted as apparently sterile. Photomicrographs of chromosome counts were made from freshly prepared slides using Nikon 80i Eclips Microscope. In order to have proper insight into morphological variation, different morphometeric characters were studied in the plants of different populations of P. pentandra (Roxb.) Benn. (Table 2).

\section{Results And Discussion}

Morphological Analysis Morphological analysis was carried out on different populations of $P$. pentandra revealed the existence of two morphotypes- the green plants and the red plants (Table 2). Green plants, most common type, collected from Rehlu (900m) and Dheera $(500 \mathrm{~m})$ showed the green stem, green midrib and pale green flowers while red plants collected from Rehlu (900m) exhibited the reddish stem, reddish mid-rib and reddish flowers. Different parameters have been studied
Table 2. Morphological comparison of two morphotypes of Pouzolzia pentandra (Roxb.) Benn. from different localities of western Himalayas, India

\begin{tabular}{|c|c|c|}
\hline & Green Morphotype & Red Morphotype \\
\hline Locality & $\begin{array}{l}\text { Rehlu, } 900 \mathrm{~m} \text { and } \\
\text { Dheera,500m }\end{array}$ & Rehlu,900m \\
\hline \multicolumn{3}{|l|}{ Plant } \\
\hline Habit & Erect herb & Erect herb \\
\hline Height(cm) & $60.8-62.1$ & 61.9 \\
\hline Habitat & $\begin{array}{l}\text { Near water channels in } \\
\text { rice fields and waste land }\end{array}$ & $\begin{array}{l}\text { Near water channels in } \\
\text { rice fields }\end{array}$ \\
\hline \multicolumn{3}{|l|}{ Stem } \\
\hline Colour & Green & Reddish \\
\hline $\begin{array}{l}\text { Internode } \\
\text { Length }(\mathrm{cm})\end{array}$ & $4.2-5.5$ & $4.8-5.6$ \\
\hline \multicolumn{3}{|l|}{ Leaf } \\
\hline Lamina $(\mathrm{cm})$ & $5.2 \times 1.3$ & $5.6 \times 1.2$ \\
\hline $\begin{array}{l}\text { Petiole } \\
\text { Length }(\mathrm{cm})\end{array}$ & 0.2 & 0.2 \\
\hline Shape & Oblong-lanceolate & Oblong-lanceolate \\
\hline Leaf margins & Entire & Entire \\
\hline Mid-rib colour & Green & Reddish \\
\hline \multicolumn{3}{|l|}{ Inflorescence } \\
\hline $\begin{array}{l}\text { Size of } \\
\text { internodes in } \\
\text { Inflorescence }(\mathrm{cm})\end{array}$ & $0.1-1.2$ & $0.1-0.8$ \\
\hline $\begin{array}{l}\text { Size of } \\
\text { bracts }(\mathrm{cm})\end{array}$ & $0.5-2.7$ & $0.9-2.0$ \\
\hline $\begin{array}{l}\text { Number of } \\
\text { flowers per } \\
\text { cluster }\end{array}$ & $5-7$ & $6-7$ \\
\hline Flower colour & Pale green & Reddish \\
\hline Pedicel colour & Pale green & Reddish \\
\hline
\end{tabular}

for comparing characteristics of two morphotypes. Significant morphological differences were observed for characteristics such as stem colour, flower colour and leaf midrib colour (Table 2). The other characteristics were similar in both the morphotypes.

Chromosome number The meiotic analysis was carried out on four populations of P. hirta (Blume) Hassk. and three populations of $P$. pentandra (Roxb.) Benn. from western Himalayas, India. The meiotic analysis of three 
0

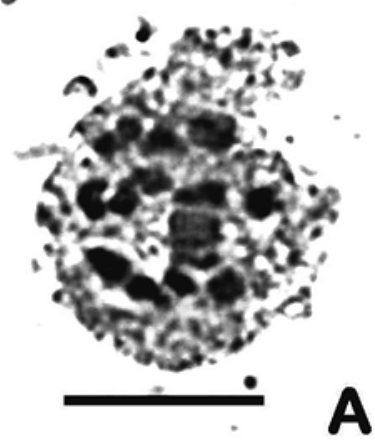

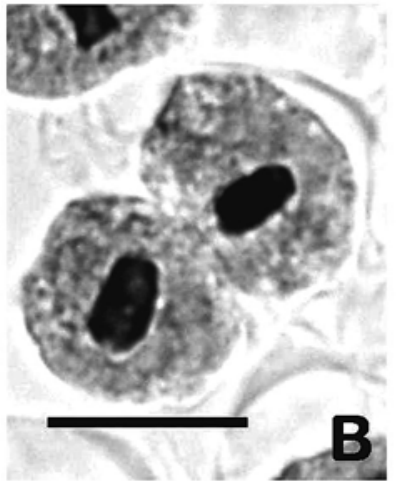
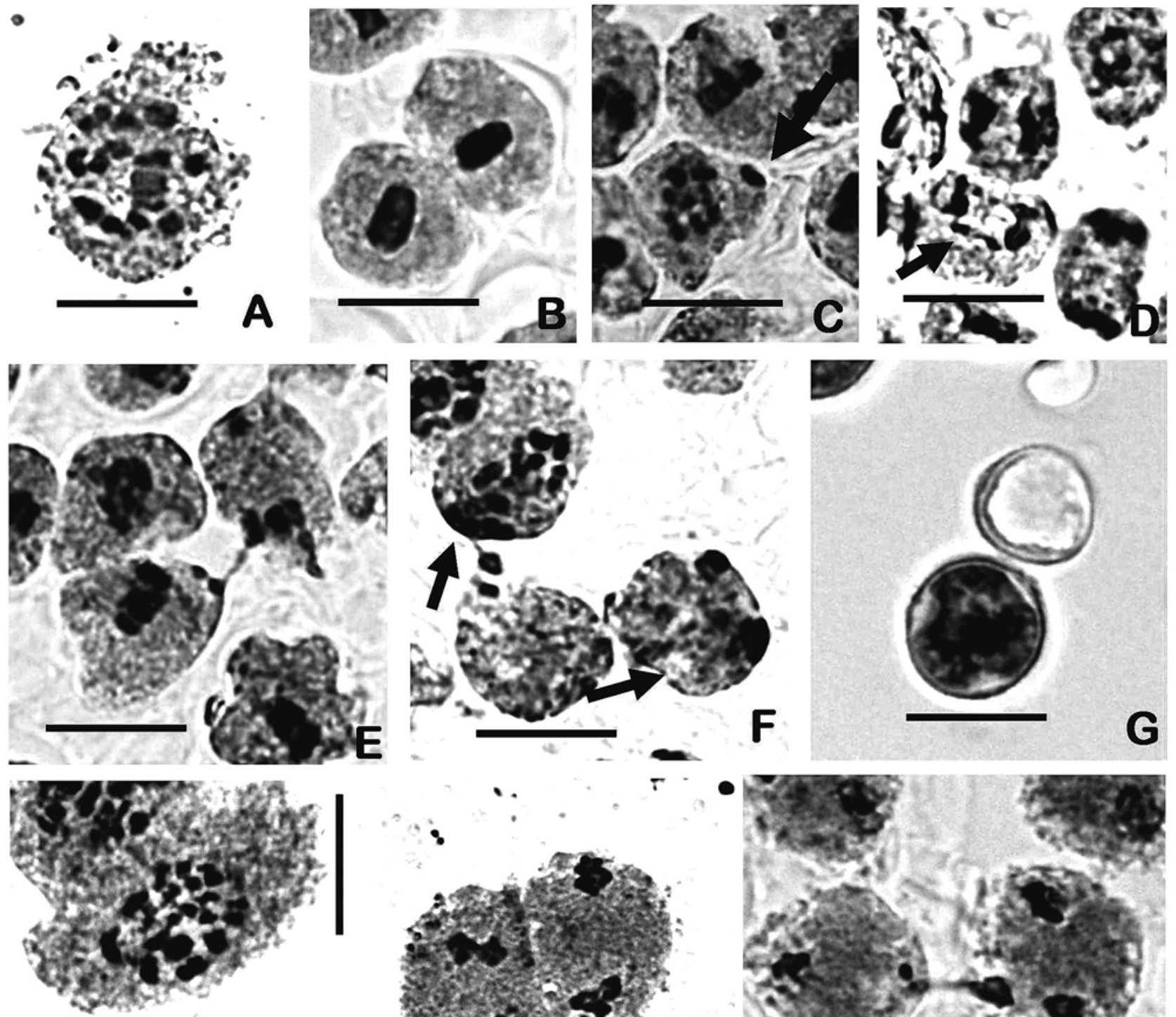

$\bullet$

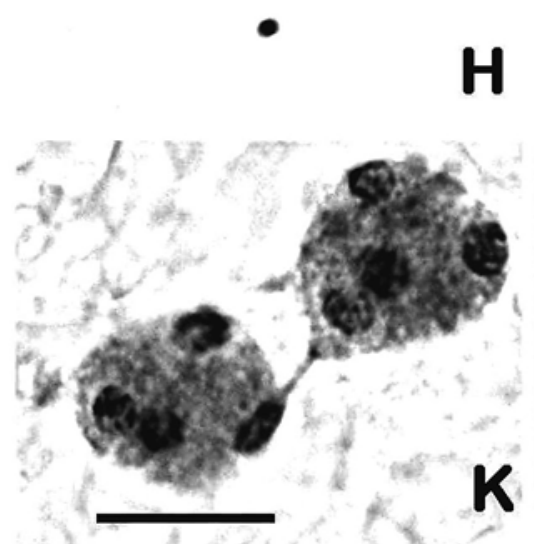

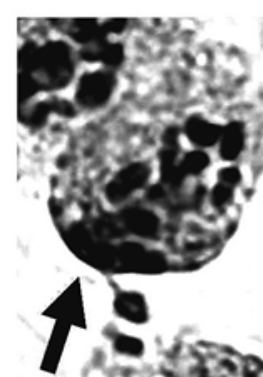

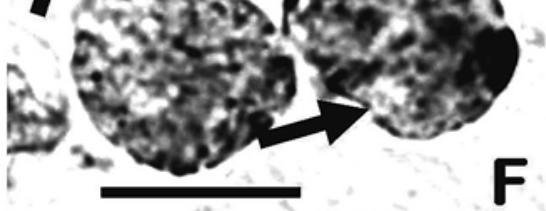

$\mathbf{F}$
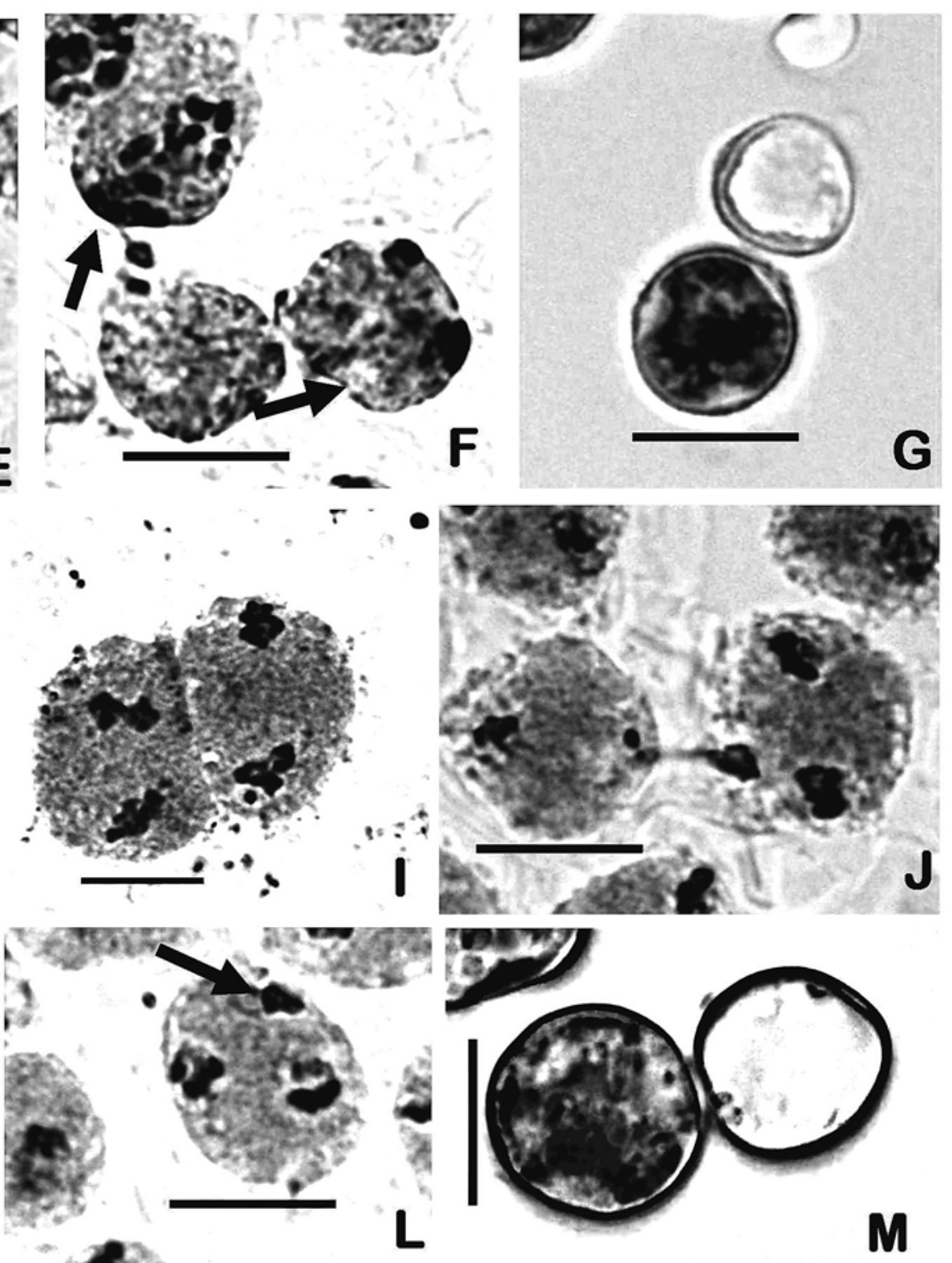

Fig. 2. A-M. Meiotic chromosome number and meiotic abnormalities in Pouzolzia hirta (A-G) and Pouzolzia pentandra (H-M). A. A PMC at diakinesis showing $13_{\mathrm{I}}$, B. PMCs with chromatin stickiness at metaphase-I, C. A PMC with extra chromatin material at metaphase-I (arrow), D. A PMC showing chromatin bridge at anaphase-I (arrow), E. Chromatin transfer among two PMCs at metaphase-I, F. A PMC showing complete transfer of chromatin material to two adjacent PMCs (arrows), G. An apparently large fertile and small sterile pollen grain, H. A PMC showing $13_{\text {II }}$ at diakinesis, I. PMCs with stickiness of chromosomes at metaphase-II, J. Transfer of chromatin material among two PMCs at metaphase-II, K. Chromatin transfer between two PMCs at telophase-II, L. extra material in PMC at metaphase-II (arrow), M. An apparently large fertile and small sterile pollen grain. Scale bar $=10 \mu \mathrm{m}$. 
populations of $P$. pentandra (Roxb.) Benn. uniformly revealed the chromosome count of $2 n=26$, confirmed by the presence of 13 bivalents at diakinesis (Fig. $2 \mathrm{H}$ ). The chromosome count of $2 \mathrm{n}=26$ in $P$. pentandra is first ever chromosome report for the species on worldwide basis. Individuals of all the four populations of $P$. hirta uniformly showed chromosome count of $2 \mathrm{n}=26$, verified by the presence of 13 bivalents at diakinesis (Fig. 2A). The cytological analysis of $P$. hirta has been carried out for the first time from western Himalayas, India and the present count of $\mathrm{n}=13$ in $P$. hirta is in conformity with the earlier chromosome record from eastern Himalayas (Sharma 1970; Guha 1977; Sharma and Mehra 1977). However, varied chromosome count of $n=8$ (Sharma 1970) and n=16 (Sharma and Sarkar 1967-1968; Sharma 1970; Chatterjee et al. 1989) was also reported earlier in the species.

Perusal of cytological literature revealed the chromosome counts in seven species of the genus Pouzolzia. The data show existence of chromosome number $2 n=16,20,22$, $24,26,32,48$ and 52 of which $2 \mathrm{n}=26$ is the most common (23.08\% species). Both the presently investigated species have $2 n=26$ and are diploid based upon base number $x=13$ as suggested by Sharma and Mehra (1979).

Meiotic Behaviour Meiotic behaviour was analysed in plant belonging to four populations of $P$. hirta and three populations of $P$. pentandra (Table 1). A wide range of meiotic stages were observed in anthers within same flower. In most of the PMCs observed in both the species, clumpiness or stickiness of chromosomes was of common occurrence (Fig. 2B, 2I). Various accessions of three populations of $P$. hirta (Beerta, 730m; Bhagsunag, 1,900m and Sali $1,500 \mathrm{~m}$ ) showed normal meiotic behavior. However in the accessions analysed from Palampur $(1,100 \mathrm{~m})$ population meiotic abnormalities like bridges at anaphase-I (Fig. 2D) and extra chromatin material (Fig. 2C) was observed. A good number of PMCs at diakinesis and metaphase-I (11.24\%) were involved in phenomenon of cytomixis. Cytoplasmic channels were observed linking 2-3 PMCs atatime(Fig. 2E, 2F). Microsporogenesis was normal leading to $92.67 \%$ pollen fertility (Table 1)

In P. pentandra apart from stickiness of chromosomes extra chromatin material was observed in few PMCs of various accessions (Fig. 2L). The accession of P. pentandra green morphotype showed few PMCs (below 5\%) involved in cytomixis whereas the red morphotype had the involvement of $12.81 \%$ of PMCs in cytomixis (Table 1). PMCs involved in cytomixis were observed to be at diakinesis, metaphase-I, telophase-I, metaphase-II and telophase-II stages (Fig. 2J, 2K). However, no adverse effect on pollen viability was seen (Table 1 ).

The most frequent cytological abnormality, chromosome stickiness may be due to genetic and environmental factors as well as genomic-environmental interaction (Nirmala and Rao 1996; Baptista- Giacomelli et al. 2000).
In the present course of study, another chromosomal aberration was bridge formation at anaphase-I. According to Subramanian and Thilagavathy (1988), bridge formation is due to inversion heterozygosity and the frequency of bridge formation depends on chiasma frequency, number of inversions and size of inversions. The formation of bridge has also been attributed to failure of chiasmata in a bivalent to terminalize and chromosome get stretched between the poles (Sayler and Smith 1966), interlocking of bivalent chromosomes (Battacharjee 1953), or paracentric inversion (Sinha and Godward 1972). Cytomixis has been reported during microsporogenesis in several families of flowering plants (Heslop-Harrison 1966; Saggoo and Bir 1983; Ghanima and Talat 2003; Lattoo et al. 2006; Singhal et al. 2008; Saggoo and Srivastava 2009; Saggoo and Lovleen 2011). Several reasons have been cited as cause of cytomixis like natural cytological phenomenon, certain environmental or physiological stress, in addition to the controlling genetic mechanisms (Omara 1976; Mantu and Sharma 1983; Falistocco et al. 1995; Bllucci et al. 2003; Lattoo et al. 2006). In spite of abnormalities there is no negative effect on the pollen viability.

Western Himalayas is very important source of medicinal plants and many are still to be explored for cytomorphological diversity. The present report is useful entry in chromosomal data base of wild medicinal plants of the region.

ACKNOWLEDGMENTS. The authors are grateful to the University Grants Commission, New Delhi for providing facilities under the DRS SAP III and ASIST programme. Financial assistance to one of us (Lovleen) by Department of Science and Technology, Government of India, New Delhi, under WOS-A is gratefully acknowledged. Thanks are also due to the Head, Department of Botany, Punjabi University, Patiala for necessary laboratory facilities.

\section{Literature Cited}

Baptista-Giacomelli, F. R., Pagliarini, M. S. and Almedia, J. L., 2000. Meiotic behavior in several Brazilian oat cultivars (Avena sativa L.). Cytologia 65: 371-378.

Bellucci, M., Roscini, C. and Mariani A. 2003. Cytomixis in pollen mother cells of Medicago sativa L. Jour. Heredity 94: 512-516.

Bhattacharjee, S. K. 1953. Cytogenetics of Lens esculanta Monesch. Caryologia 5: 159-166.

Chaichanawongsaroj, N., Amonyingcharoen S., Pattiyathanee P., Vilaichone R. and Poovorawan Y. 2012. AntiHelicobacter pylori and anti-internalization activities of Thai folk remedies used to treat gastric ailments. Jour. Med. Pl. Res. 6(8): 1389-1393.

Chatterjee, A., Gosh S. and Roy S.C. 1989. A cytological survey of eastern Himalayan plants III. Cell Chrom. Res. 12: $22-29$.

Falistocco, E., Tosti, N. and Falcinelli, M. 1995. Cytomixis in pollen mother cells of diploid Dactylis one of the origins of $2 \mathrm{n}$ gametes. Jour. Heredity 86: 448-453.

Ghanima, A. M. and Talat, A. A. 2003. Cytomixis and its possible evolutionary role in a Kuwait population of Diplotaxis harra (Boraginaceae). Bot. Jour. Linn. Soc. 143: 169-175.

Guha, S. 1977. Cytology of some members of Urticaceae. Proc. Ind. Sci. Congr. Assoc. 64: 148-149. 
Heslop-Harrison, J. 1966. Cytoplasmic connections between angiosperm meiocytes. Ann. Bot. 30: 221-234.

Lattoo, S. K., Khan, S., Bamotra, S. and Dhar, A. K. 2006. Cytomixis impairs meiosis and influences reproductive success in Chlorophytum comosum (Thunb) Jacq. - an additional strategy and possible implications. Jour. Biosci. 31: 629-637.

Mantu, D. E. and Sharma, A. K. 1983. Cytomixis in pollen mother cells of an apomictic ornamental Ervatamia divaricata Linn. Alston. Cytologia 48: 201-207.

Marks, G. E. 1954. An acetocarmine glycerol jelly for use in pollen fertility counts. Stain Tech. 29: 277.

Nirmala, A. and Rao, P. N. 1996. Genetics of chromosome numerical mosaism in higher plants. The Nucleus 39: 151-175.

Omara, M. K. 1976. Cytomixis in Lolium perenne. Chromosoma 55: $267-271$

Saggoo, M. I. S. and Bir, S. S. 1983. Cytomixis in certain members of Acanthaceae and Labiateae from India. Jour. Cytol. Genet. 18: 92-99.

Saggoo, M. I. S. and Srivastava, D. K. 2009. Meiotic studies in some species of Pedicularis L. from cold desert regions of Himachal Pradesh, India (North-west Himalaya). Chrom. Bot. 4: 83-86.

Saggoo, M. I. S. and Lovleen 2011. Male meiosis and microspogenesis in west Himalayan Cyathula capitata Moq. Chrom. Bot. 6:125-128

Saha J., Sarkar P.K., Chattopadhyay S. 2011. A survey of ethnomedicinal plants of Darjeeling hills for their antimicrobial and antioxidant activities. Ind. Jour. Nat. Prod. Res. 2(4): 479-492.
Saylor, L. C. and Smith B. W. 1966. Meiotic irregularity in species and interspecific hybrids of Pinus. Am. Jour. Bot. 5: 453-468

Shankar, R. and Devalla R. B. 2012. Conservation of folk healing practices and commercial medicinal plants with special reference to Nagaland. Inter. Jour. Biod. Cons. 4(3): 155-163.

Sharma, A. and Sarkar A. K. (editors). 1967-68. Chromosome number report of plants in Annual report, Cytogenetics Laboratory, Department of Botany, University of Calcutta. The Res. Bull. 2: 38-48.

Sharma, A. K. 1970. Annual Report, 1967-68. University of Calcutta (Cytogenetics lab). Res. Bull. 2: 1-50.

Sharma, M. L. and Mehra, P. N. 1977. In IOPB chromosome number reports LVII. Taxon 26: 443-452.

Sharma, M. L. and P. N. Mehra. 1979. Chromosome number in some east Himalyan Urticaceae. Cytologia 44: 799-808.

Singhal, V. K., Kaur, D. and Kumar, P. 2008. Effect of Cytomixis on the pollen size in 'Seeabuckthorn'(Hippophae rhamnoides L., Elaegnaceae). Cytologia 73: 167-172.

Sinha, S. S. N. and Godward, M. B. E. 1972. Radiation studies in Lens culinaris. Ind. Jour. Genet. 32: 331-339.

Srivastava, R. C. 2009. Traditional knowledge of Adi tribe of Arunachal Pradesh on plants. Ind. Jour. Trad. Knowl. 8(2): 146-153.

Subramaniam, D. and Thilagavathy, A. 1988. Cytotaxonomical studies of south Indian Urticaceae. Cytologia 53: 671678

Wilmot-Dear, C. M. and Friis, I. 2004. The old world species of Pouzolzia (Urticaceae, tribus Boehmeieae). A taxonomic revision. Nord. Jour. Bot. 24(1): 5-111. 
